\title{
Patterns of Status Epilepticus-Induced Neuronal Injury during Development and Long-Term Consequences
}

\author{
Raman Sankar, ${ }^{1,2,3}$ Don H. Shin, ${ }^{1,2,3}$ Hantao Liu, ${ }^{1,3}$ Andrey Mazarati, ${ }^{1,3}$ Anne Pereira de Vasconcelos, ${ }^{4}$ and \\ Claude G. Wasterlain ${ }^{1,3}$ \\ Departments of ${ }^{1}$ Neurology and ${ }^{2}$ Pediatrics, University of California Los Angeles School of Medicine, Los Angeles, \\ California 90095-1752, ${ }^{3} E$ pilepsy Research Laboratories, Veterans Affairs Medical Center, Sepulveda, California 91343, \\ and ${ }^{4}$ Institut National de la Santé et de la Recherche Médicale U 398, 67085 Strasbourg. France
}

The lithium-pilocarpine model of status epilepticus (SE) was used to study the type and distribution of seizure-induced neuronal injury in the rat and its consequences during development. Cell death was evaluated in hematoxylin- and eosinstained sections and by electron microscopy. Damage to the CA1 neurons was maximal in the 2- and 3-week-old pups and decreased as a function of age. On the other hand, damage to the hilar and CA3 neurons was minimal in the 2-week-old rat pups but reached an adult-like pattern in the 3-week-old animals, and damage to amygdalar neurons increased progressively with age. The 3-week-old animals also demonstrated vulnerability of the dentate granule cells. To evaluate neuronal apoptosis, we used terminal deoxynucleotidyl transferasemediated biotinylated UTP nick end labeling (TUNEL) stain, confocal fluorescence microscopy of ethidium bromide-stained sections, electron microscopy, and DNA electrophoresis. Neu- rons displaying all of those features of apoptotic death in response to SE were seen in the CA1 region of the 2-week-old pups and in the hilar border of the dentate granule cells of the 3 -week-old animals. Some (3/11) of the animals that underwent SE at 2 weeks of age and most of the animals that underwent SE at 3 or 4 weeks of age (8/11 and 6/8, respectively) developed spontaneous seizures later in life; the latter showed SEinduced synaptic reorganization as demonstrated by Timm methodology. These results provide strong evidence for the vulnerability of the immature brain to seizure-induced damage, which bears features of both necrotic and apoptotic death and contributes to synaptic reorganization and the development of chronic epilepsy.

Key words: status epilepticus; seizures; lithium; pilocarpine; hippocampus; apoptosis; necrosis; mossy fiber sprouting; epileptogenesis; rats; development
In adult animals, seizures cause selective neuronal death as a result of excessive neuronal activation, even in the absence of systemic complications (Meldrum et al., 1973; Nevander et al., 1985). Status epilepticus (SE) can produce neuronal damage by excessive activation of both NMDA and non-NMDA ionotropic glutamate receptors, and both NMDA and non-NMDA receptor antagonists have demonstrated neuroprotective properties in various seizure paradigms (Fujikawa, 1994, 1995; Penix and Wasterlain, 1994; Penix et al., 1996). Different neuronal populations in the hippocampus demonstrate selectively apoptotic or necrotic features of cell death in response to perforant path stimulation, a model of focal SE (Sloviter et al., 1996). Administration of kainic acid (KA) by intra-amygdaloid (Pollard et al., 1994), subcutaneous (Morrison et al., 1996), or intraperitoneal (Filipkowski et al., 1994) route results in SE and apoptosis of select populations of neurons. In the intra-amygdaloid model (Pollard et al., 1994), coadministration of diazepam prevented the seizures and apoptosis of neurons in the CA3 region, but not in the amygdala,

Received May 27, 1998; revised Aug. 3, 1998; accepted Aug. 7, 1998.

R.S. was supported by Clinical Investigator Development Award NS01792 from the National Institute of Neurological Disorders and Stroke (NINDS), National Institutes of Health. C.G.W. was supported by Grant NS13515 from NINDS, National Institutes of Health, and by the Research Service of the Veterans Health Administration. We thank Roger Baldwin, Rosie Lezama, Steve Shinmei, and Don Santos for technical assistance.

Correspondence should be addressed to Dr. Raman Sankar, Pediatric Neurology (22-474 Marion Davies Children's Center), Box 951752, UCLA School of Medicine, Los Angeles, CA 90095-1752.

Copyright (C) 1998 Society for Neuroscience $\quad 0270-6474 / 98 / 188382-12 \$ 05.00 / 0$ suggesting that the apoptotic hippocampal neurons reflect seizure-induced excitotoxic damage.

In the developing brain, the effect of seizures on neuronal survival and brain growth have been controversial (Camfield, 1997; Wasterlain, 1997). Excitotoxic neuronal death is influenced by brain maturation (Portera-Cailliau et al., 1997a,b). Because apoptosis plays an important role in early brain development it is possible that the immature brain displays a special vulnerability to programmed cell death in response to seizures. Animal models suggest the existence in the young of both unique protective mechanisms as well as enhanced vulnerability to specific types of experimental SE (Sankar et al., 1995). Rat pups as young as 2 weeks demonstrate seizure-induced elevation in serum neuronspecific enolase accompanied by histological evidence of damage as a result of SE (Sankar et al., 1997b). Our understanding of seizure-induced brain damage in immature animals remains patchy because available reports are based on a limited sampling of models and ages (Albala et al., 1984; Okada et al., 1984; Sperber et al., 1991, 1992; Thompson and Wasterlain, 1997; Thompson et al., 1998), or they have examined specific aspects such as EEGs (Hirsch et al., 1992) or behavior (Liu et al., 1994) without a detailed study of the histopathology.

The cholinergic agent pilocarpine (PC) produces limbic and generalized $\mathrm{SE}$ in rodents accompanied by widespread brain damage in mature rats (Turski et al., 1983). The use of PCinduced seizures as a model for studying SE and SE-induced brain damage and epileptogenesis has been well described (Cavalheiro, 1995; Cavalheiro et al., 1996). Furthermore, the suscep- 
tibility of rats to PC-induced seizures appeared to be agedependent (Cavalheiro et al., 1987). Clifford and collaborators (1987) have shown that pretreatment with lithium (Li) potentiates the epileptogenic action of PC (Honchar et al., 1983; Jope et al., 1986), reduces mortality, and avoids many of the peripheral cholinomimetic side effects of PC.

We report here the pattern of apoptosis and necrosis resulting from SE induced by the administration of lithium and pilocarpine in both developing and adult rat brains. Both morphological and biochemical methods have been used to detect the pattern of seizure-induced brain damage at different developmental stages. We also report the development of spontaneous seizures and seizure-associated synaptic plasticity in the mossy fiber terminals as visualized by Timm histochemistry.

Some of the results have appeared previously in abstract form (Sankar et al., 1997a).

\section{MATERIALS AND METHODS}

Animals. Wistar rats (Simonsen Labs, Gilroy, CA) of either sex were used in this study. The Committees on Animal Research at the University of California, Los Angeles, and the Sepulveda Veterans Affairs Medical Center approved all protocols. Rat pups of 2, 3, and 4 weeks of age and mature rats (12-16 weeks of age) were given $3 \mathrm{mEq} / \mathrm{kg}$ lithium chloride (Sigma, St. Louis, MO) intraperitoneally on the day before the induction of SE. Seizures progressing to SE were induced by subcutaneous injection of $60 \mathrm{mg} / \mathrm{kg}$ pilocarpine hydrochloride (Sigma). Control animals were given an equal volume of saline subcutaneously. Rats were observed for behavioral evidence of seizures. Only rats displaying behavioral manifestations of seizures described previously (Jope et al., 1986; Hirsch et al., 1992) were used. The selected animals underwent blood gas monitoring 5 min before the administration of PC, and 2, 4, and $6 \mathrm{hr}$ after. We have previously recorded electrographic seizures from both the hippocampus and parietal cortex of selected animals of each age and have previously published selected epochs (Kornblum et al., 1997). A detailed ontogenetic study of the EEG during lithium-pilocarpine (LiPC)induced SE has been published by Hirsch et al. (1992).

Histology. The animals were subjected to methoxyflurane (Mallinckrodt, Mundelein, IL) anesthesia $24 \mathrm{hr}$ after the pilocarpine treatment. Subsequently, they underwent transcardiac perfusion-fixation with PBS followed by $4 \%$ phosphate-buffered paraformaldehyde. Brains were left in situ for $2 \mathrm{hr}$ and then put in $4 \%$ paraformaldehyde overnight. Each brain was then dehydrated in graded ethanol solutions, cleared with D-limonene (Fisher, Santa Clara, CA), embedded in paraffin, sectioned to $8 \mu \mathrm{m}$ thickness, deparaffinized and hydrated, and stained with modified hematoxylin and eosin. Slides were examined under fluorescent light so that cells that sustained injury and became acidophilic (eosinophilic) could be identified by their bright eosin fluorescence as described in detail earlier (Sankar et al., 1997b). Bilateral sections of the dorsal hippocampus approximating the region $-3.8 \mathrm{~mm}$ posterior to bregma (Paxinos and Watson, 1982) were used for cell counts of subfields CA1, CA3, and hilus. A few animals were maintained for 6 months after SE and then killed for examination of Nissl-stained sections. Tissue was cut into $30 \mu \mathrm{m}$ sections and stained with cresyl violet.

Terminal deoxynucleotidyl transferase-mediated biotinylated UTP nick end labeling staining. Paraffin-embedded sections were labeled with a commercially available in situ labeling kit (Oncor, Gaithersburg, MD). Briefly, sections were deparaffinized in D-limonene (Fisher), incubated with proteinase $\mathrm{K}$ (Oncor) followed by terminal deoxynucleotidyl transferase and biotinylated-16-dUTP. The reaction product was visualized
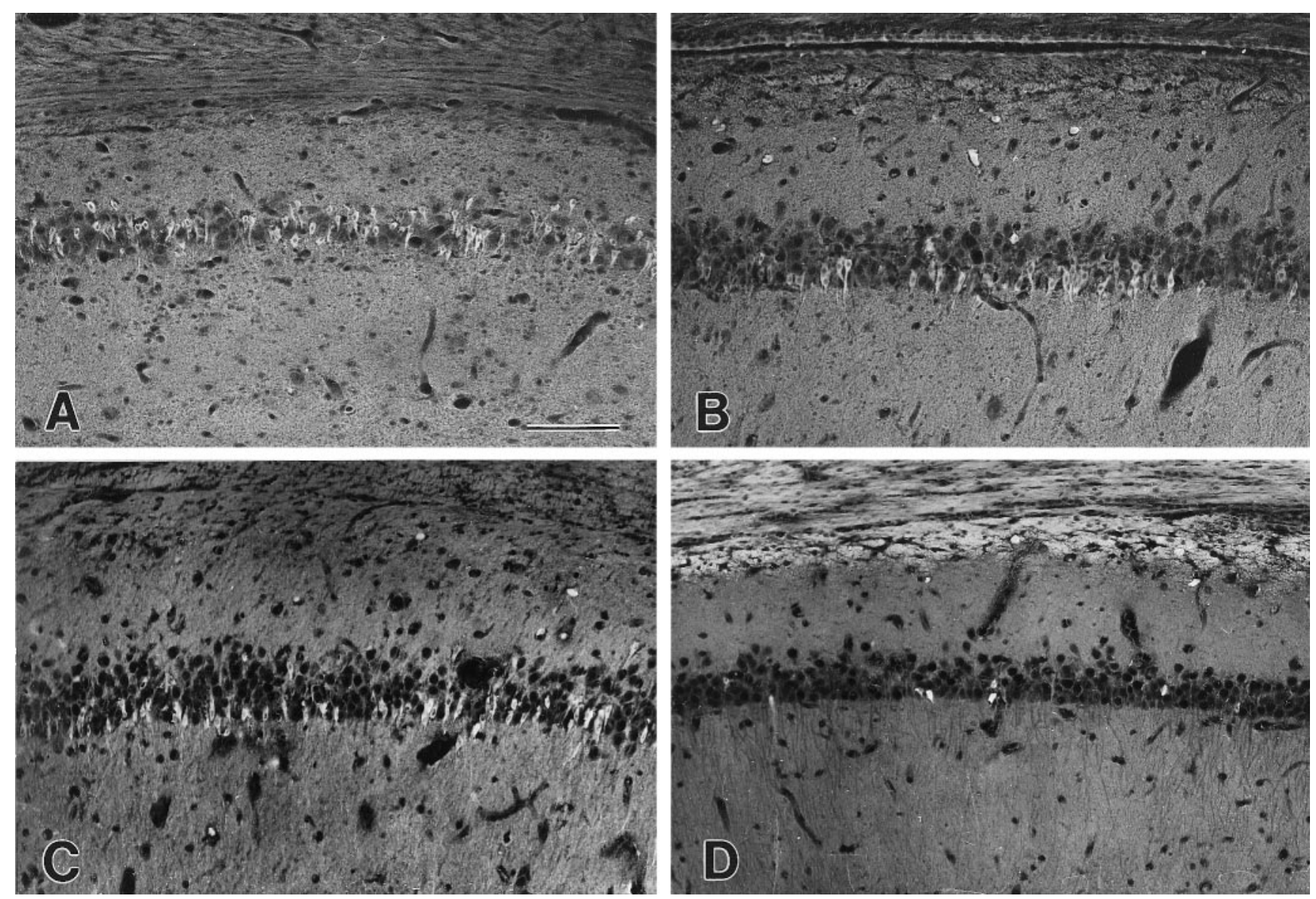

Figure 1. Histological lesions in lithium-pretreated rats $24 \mathrm{hr}$ after SE from pilocarpine administration. CA1 of a 2-week-old $(A)$, 3-week-old ( $B)$, and 4-week old pup $(C)$ shows a large number of eosinophilic cells that fluoresce brightly (hematoxylin and eosin), whereas the CA1 of a mature rat $(D)$ has scattered damage. Scale bar, $100 \mu \mathrm{m}$. 


\begin{tabular}{|c|c|c|c|c|c|}
\hline & Age (week) & $\begin{array}{l}\text { Number of } \\
\text { acidophilic neurons }\end{array}$ & $\begin{array}{l}\text { Number of } \\
\text { normal neurons }\end{array}$ & $\begin{array}{l}\text { Total number } \\
\text { of neurons }\end{array}$ & $\begin{array}{l}\text { Percent acido- } \\
\text { philic neurons }\end{array}$ \\
\hline \multirow[t]{4}{*}{ CA1 } & 2 & $107 \pm 17$ & $192 \pm 20$ & $299 \pm 25$ & $36 \pm 5$ \\
\hline & 3 & $98 \pm 30$ & $185 \pm 8$ & $283 \pm 17$ & $34 \pm 10$ \\
\hline & 4 & $70 \pm 22$ & $232 \pm 28$ & $302 \pm 14$ & $24 \pm 8$ \\
\hline & $9-12$ & $22 \pm 7$ & $251 \pm 13$ & $273 \pm 10$ & $9 \pm 3^{a}$ \\
\hline \multirow[t]{4}{*}{ CA3 } & 2 & $4 \pm 0.8$ & $344 \pm 19$ & $348 \pm 19$ & $1 \pm 0.2^{b}$ \\
\hline & 3 & $62 \pm 19$ & $244 \pm 41$ & $306 \pm 28$ & $20 \pm 9$ \\
\hline & 4 & $58 \pm 14$ & $262 \pm 30$ & $320 \pm 18$ & $18 \pm 7$ \\
\hline & $9-12$ & $43 \pm 7$ & $275 \pm 19$ & $318 \pm 16$ & $14 \pm 3$ \\
\hline \multirow[t]{4}{*}{ Hilus } & 2 & $1.0 \pm 0.4$ & $72 \pm 3$ & $73 \pm 3$ & $1 \pm 0.5^{c}$ \\
\hline & 3 & $23 \pm 2$ & $52 \pm 3$ & $75 \pm 4$ & $31 \pm 2$ \\
\hline & 4 & $16 \pm 1$ & $55 \pm 2$ & $71 \pm 3$ & $27 \pm 2$ \\
\hline & $9-12$ & $20 \pm 1$ & $52 \pm 3$ & $72 \pm 3$ & $28 \pm 2$ \\
\hline \multirow[t]{4}{*}{ GC } & 2 & $41 \pm 5$ & $827 \pm 33$ & $868 \pm 34$ & $5 \pm 0.5$ \\
\hline & 3 & $296 \pm 51$ & $636 \pm 70$ & $932 \pm 36$ & $33 \pm 7^{c}$ \\
\hline & 4 & $65 \pm 14$ & $875 \pm 28$ & $940 \pm 24$ & $7 \pm 2$ \\
\hline & $9-12$ & $43 \pm 6$ & $833 \pm 19$ & $876 \pm 19$ & $5 \pm 1$ \\
\hline
\end{tabular}

Data are presented as mean \pm SEM number of neurons per slide adding up the left and right hippocampal counts.

${ }^{a} p<0.05$ compared with 2 - and 3-week-old animals.

${ }^{b} p<0.05$ compared with 3 - and 4-week-old animals.

${ }^{c} p<0.001$ compared with all other age groups.

with diaminobenzidine (Sigma) and lightly counterstained with $1 \%$ methyl green (Sigma).

Ethidium bromide staining. Some animals were perfused as described above, and the brains were removed, cryoprotected in 30\% sucrose, and then cut in $30 \mu \mathrm{m}$ frozen sections. Sections were soaked in D-limonene (Fisher), hydrated to water, stained in ethidium bromide (EtBr) $(0.1$ $\mu \mathrm{g} / \mathrm{ml}$ ) for $3 \mathrm{~min}$, rinsed in water, and then dehydrated before mounting. Slides were viewed under fluorescent light using a rhodamine filter.

Optical sections were also obtained with an Olympus IX-70 microscope equipped with an epifluorescence adapter and a $100 \times$ oil immersion objective lens. Images were recorded with the CELLscan System (Scanalytics, Billerica, MA) equipped with a SenSys CCD camera system (Photometrics, Tucson, AZ), a piezoelectric $z$-axis focus device, and a computer-controlled excitation light shutter. The light haze contributed by fluorescently labeled structures located above and below the plane of optimal focus was mathematically reassigned to its proper places of origin (Exhaustive Photon Reassignment software, Scanalytics) after accurate characterization of the blurring function of the optical system. The blurring function of the optical system (the point-spread function) was characterized by imaging a through-focus series of optical sections of a 0.2- $\mu \mathrm{m}$-diameter fluorescent bead (Molecular Probes, Eugene OR) using the same optical conditions as those used to obtain the specimen image. The patented Exhaustive Photon Reassignment (EPR) process successively iterates estimates of the true signal and intensity distribution until such time as the estimate, when blurred by the point-spread function, yields the image as detected by the camera. This can be expressed as follows: $I=O * P S F$, where $I=$ image of the object as detected by the camera, $O=$ the true object as it exists on the microscope slide, ${ }^{*}=$ convolution, $P S F=$ point-spread function image stack as measured from the optical setup. During restoration, EPR uses the PSF image data to refocus light and haze in the raw specimen image.

DNA extraction and agarose gel electrophoresis. Samples of hippocampi $(8-10)$ were dissected from fresh brains of rats ( $24 \mathrm{hr}$ after SE), immediately frozen in dry ice, and stored at $-70^{\circ} \mathrm{C}$ until use. DNA was purified using the technique of Iwasa et al. (1996). Hippocampi were incubated overnight in digestion buffer [ $100 \mathrm{~mm} \mathrm{NaCl}, 10 \mathrm{~mm}$ Tris-Cl, $\mathrm{pH} 8.0,25$ mM EDTA, $\mathrm{pH} 8.0,0.5 \%$ SDS, $0.1 \mathrm{mg} / \mathrm{ml}$ proteinase $\mathrm{K}, 0.1 \mathrm{mg} / \mathrm{ml}$ RNase A (Sigma)]. DNA was extracted using equal proportions of the lysate and phenol, chloroform, and isoamyl alcohol (Life Technologies, Gaithersburg, MD). The aqueous layer was incubated at $37^{\circ} \mathrm{C}$ with additional RNase A $(0.1 \mathrm{mg} / \mathrm{ml})$ for $60-90 \mathrm{~min}$. Phenol extraction was repeated and DNA was precipitated with $2.5 \mathrm{vol}$ of ethanol and $1 / 10 \mathrm{vol}$ of sodium acetate and placed in dry ice for $30 \mathrm{~min}$. Precipitated DNA was spun at $11,000 \mathrm{rpm}(14,500 \times \mathrm{g})$ for $15 \mathrm{~min}$ and washed three times with $50 \mathrm{ml}$ cold $70 \%$ ethanol. The supernatant was then decanted, and the pellet was air-dried for $15 \mathrm{~min}$. Pellet was resuspended in $200-500 \mu \mathrm{l}$ of $10 \mathrm{~mm}$ Tris-Cl, $\mathrm{pH} 8.5$, in $55^{\circ} \mathrm{C}$ shaking water bath overnight. Spectrophotometry revealed $A_{260 / 280}$ ratios of 1.6-2.1, indicating relatively pure DNA in concentrations of $\sim 1-4 \mu \mathrm{g} / \mu \mathrm{l}$. DNA $(20 \mu \mathrm{g}$ per lane) was run on $2 \%$ agarose gels containing $0.5 \% \mathrm{EtBr}$ at $4 \mathrm{~V} / \mathrm{cm}$ gel length. The gel was viewed under UV transillumination $(302 \mathrm{~nm})$ and photographed with a Polaroid camera.

Electron microscopy. Some animals were perfused with PBS $(20 \mathrm{ml}$ for 2-week-old animals, $30 \mathrm{ml}$ for 3-week-old animals) followed by $3 \%$ glutaraldehyde $(50 \mathrm{ml}$ for 2-week-old animals, $60 \mathrm{ml}$ for 3-week-old animals) (Electron Microscopy Sciences, Ft. Washington, PA) and 1\% paraformaldehyde (Fisher) in $0.1 \mathrm{M}$ phosphate buffer (PB), pH 7.4. The brain was removed and post-fixed for $1 \mathrm{~d}$ and then cut on a vibratome into $100 \mu \mathrm{m}$ sections. The sections were washed with $\mathrm{PB}$, stained for $1 \mathrm{hr}$ in $2 \% \mathrm{OsO}_{4}$ (Electron Microscopy Sciences), and stained en block in 2\% aqueous uranyl acetate (Mallinckrodt) for $30 \mathrm{~min}$. The sections were then dehydrated in ascending graded solutions of alcohol for 10 min each and then placed in 1:1 100\% EtOH/propylene oxide for $5 \mathrm{~min}$ followed by two incubations in propylene oxide for $5 \mathrm{~min}$. The sections were then incubated in 1:1 and 1:3 propylene oxide/Durcupan (Fluka, Buchs, Switzerland) for $1 \mathrm{hr}$ each followed by Durcupan overnight. The sections were placed between strips of Aclar plastic and cured for $24 \mathrm{hr}$ at $60^{\circ} \mathrm{C}$, after which they were cut on an ultramicrotome. They were placed on single hole grids, covered by butvar, stained with $6 \%$ uranyl acetate and lead citrate, and examined with a Philips Electron Microscope 201C.

Timm histochemistry. Rats that had been subjected to LiPC-induced SE 4 months earlier and control rats were anesthetized with methoxyflurane (Mallinckrodt) and perfused transcardially with an aqueous solution of $250 \mathrm{ml}$ of $0.1 \%$ (w/v) sodium sulfide, followed by $250 \mathrm{ml}$ of $4 \%$ paraformaldehyde solution. The brains were removed and left in a $30 \%$ (w/v) sucrose solution in the fixative overnight at $4^{\circ} \mathrm{C}$. Coronal $30 \mu \mathrm{m}$ frozen sections were developed in the dark for $30 \mathrm{~min}$ in a 6:3:1 mixture of gum arabic $(20 \%, \mathrm{w} / \mathrm{v})$, hydroquinone $(5.6 \%, \mathrm{w} / \mathrm{v})$, citric acid-sodium citrate buffer with $1.5 \mathrm{ml}$ of a silver nitrate solution (17\%) (Danscher, 1981).

Monitoring for spontaneous seizures. Animals that underwent LiPCinduced SE were selected for monitoring when they began to demonstrate behavioral seizures 3 months or longer after the initial experiments. Animals were anesthetized with ketamine $(60 \mathrm{mg} / \mathrm{kg})$ and xylazine $(15 \mathrm{mg} / \mathrm{kg})$. A bipolar stimulating electrode was implanted into the angular bundle of the perforant path $(4.5 \mathrm{~mm}$ left of and $0.5 \mathrm{~mm}$ posterior to lambda), and a bipolar recording electrode was implanted into the granule cell layer of the ipsilateral dentate gyrus $(2.2 \mathrm{~mm}$ left of 

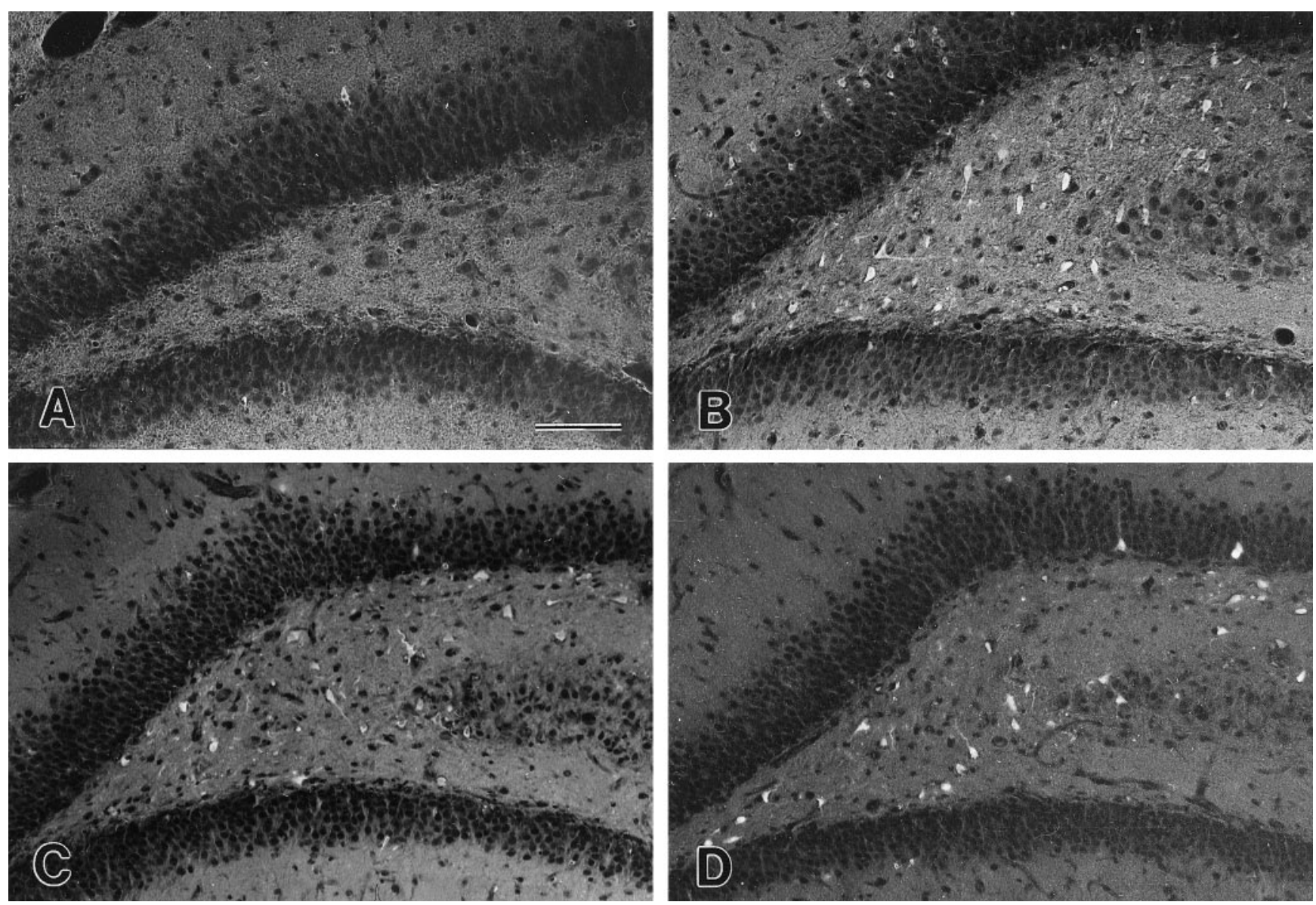

Figure 2. Dentate granule cells and hilar interneurons are damaged after pilocarpine seizures in rats pretreated with lithium. Scattered eosin fluorescence is seen in a 2-week-old pup $24 \mathrm{hr}$ after SE $(A)$. A 3-week-old pup shows extensive damage to the hilar and outer granule cells $(B)$. Damaged hilar cells are also visible in a 4-week-old $(C)$ and an adult rat $(D)$. Scale bar, $100 \mu \mathrm{m}$.

and $3.5 \mathrm{~mm}$ anterior to lambda). The depth of both electrodes was optimized by finding the population spike of maximal amplitude, evoked from the dentate gyrus by stimulation of the perforant path. After recovery from surgery for 1 week, the animals were monitored for $24 \mathrm{hr}$ a day with a video camera and continuous EEG using the Monitor 81 program from Stellate Software. The software was configured to detect and save seizures and spikes. The EEGs were analyzed off-line using the same software.

\section{RESULTS}

\section{Behavioral effects}

The $60 \mathrm{mg} / \mathrm{kg}$ dose of pilocarpine used in this study produced cortical and subcortical SE in all the ages studied (EEG data not shown). The latency to SE was 10-20 min for all ages. The 2-week-old pups developed head bobbing followed by intermittent forelimb clonus and hyperextension of the tail (which persisted for most of the duration of the SE) and of the hindlimbs intermittently. The 3- and 4-week-old rats showed forelimb clonus leading to frequent kindled-like seizures with rearing and falling, and occasional running seizures with vocalization, which sometimes culminated in tonic extension and death. The adults exhibited forelimb clonus and kindled-like seizures with frequent periods of behavioral arrest during which chewing movements and twitching of the face and/or vibrissae were often observed. All the 2-week-old rat pups survived the lithium-pilocarpine SE, whereas approximately one-third of the 3- and 4-week-old animals and $50 \%$ of the adult animals died. Arterial blood gases were sampled in the 2-week-old group (data not shown), and none of the animals experienced any hypoxemia during SE.

\section{Histological changes}

In all four groups, extensive hippocampal and extra-hippocampal neuronal death followed SE. However, both the nature and the distribution of this neuronal death were highly age-specific.

Neuronal damage in the CA1 subfield of the hippocampus (Fig. $1 A-D)$ as ascertained by the presence of "ischemic cell change" (Brown and Brierley, 1968) with a pyknotic nucleus and an eosinophilic cytoplasm was maximal in the 2- and 3-week-old rat pups (in which $36 \pm 5 \%$ and $34 \pm 10 \%$ of CA1 neurons, respectively, had this appearance) and decreased progressively with age to $25 \pm 8 \%$ in the 4 -week-old animals and $9 \pm 3 \%(p<0.05)$ in the adults (Table 1).

The neuronal damage in the CA3 region of the 2-week-old rats was barely discernible at $1 \%$. The damage at 3, 4, and 9-12 weeks $(20 \pm 9,18 \pm 7$, and $14 \pm 3 \%$, respectively) did not differ significantly (Table 1). Two-week-old rat pups were resistant to SE-induced hilar damage. The extent of damage in the 3-weekold rat pups $(31 \pm 2 \%)$ was comparable to that in the 4-week-old $(27 \pm 2 \%)$ and adult rats $(28 \pm 2 \%)$ (Table 1, Fig. $2 A-D)$. Damage to the dentate granule cells is also shown in Figures $2 A-D$. The 3 -week-old rat pups demonstrated a special vulnerability to SE-induced damage in this cell population $(33 \pm 7 \%)$ that is different from that seen in younger or older animals $(5 \pm$ 

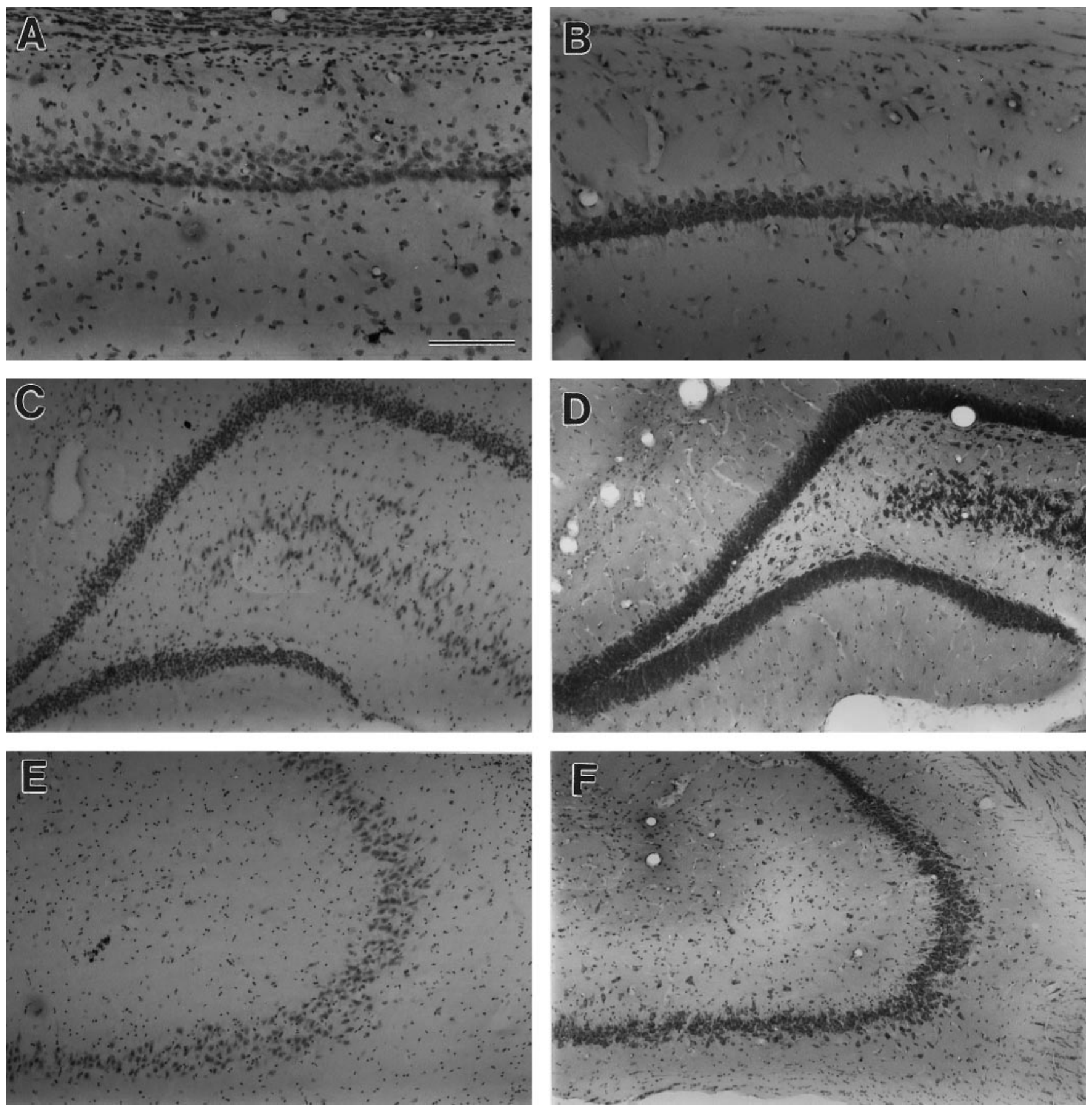

Figure 3. Permanent cell loss is seen several months after SE as pups. Cresyl violet staining shows a reduction of cells in the CA1 region of a rat subjected to LiPC at 2 weeks $(A)$ when compared with that of a control $(B) 6$ months after treatment. The hilus of a rat treated with LiPC at 3 weeks $(C)$ lacks many of the large cells seen within the tip of the hilus and in the region between the superior blade of the dentate granule cell layer and the CA3c neurons of a control $(D)$. Cell loss is also seen in the CA3a region of a rat given LiPC at 3 weeks of age $(E)$ as compared with a control $(F)$. Scale bar (shown in $A$ ): $A, B, 200 \mu \mathrm{m} ; C-F, 100 \mu \mathrm{m}$.

$0.5,7 \pm 2$, and $5 \pm 1 \%$ in $2-$, 4-, and 9-12-week-old animals, respectively) (Table 1, Fig. $2 A-D$ ). The cell injury demonstrated by eosin fluorescence at $24 \mathrm{hr}$ after SE was confirmed as permanent loss of cells by cresyl violet-stained sections in selected animals 6 months after the initial SE (Fig. $3 A-F$ ). We have reported previously on the age-related SE-induced damage to extrahippocampal structures (Sankar et al., 1997b). The neocortex, caudate, and septum showed damage scores similar to adults by 3 weeks of age, whereas the damage to amygdala showed a trend toward progressively increasing damage with age. Damage to the thalamus was maximal in the 2- and 3-week-old rats and decreased with age (Sankar et al., 1997b).

\section{Type of neuronal death}

Terminal deoxynucleotidyl transferase-mediated biotinylated UTP nick end labeling (TUNEL) stain-positive neurons were 

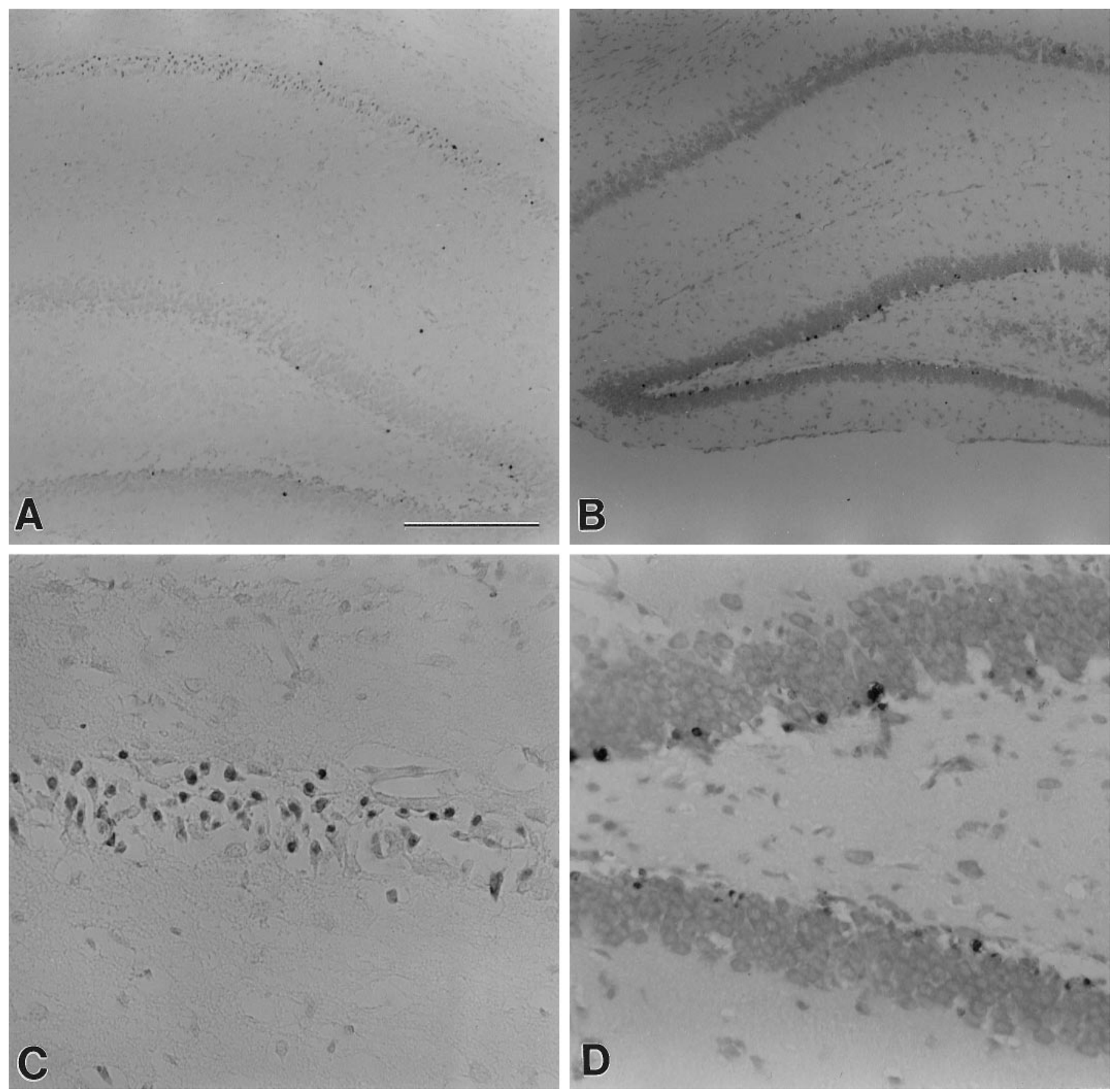

Figure 4. Comparison of the distribution of a TUNEL-stained section in 2-week-old and 3-week-old rat. Note that TUNEL label in the CA1 of the 2-week-old pup $(A, C)$ overlaps with the hematoxylin- and eosin-labeled cells (Fig. 1A), whereas the TUNEL label in the inner granule cell layer in a 3 -week-old pup $(B, D)$ is distinct from the fluorescent cells visualized under UV light (Figs. 1B, 2B). Scale bar (shown in $A$ ): $A, B, 200 \mu \mathrm{m}$ : $C, D, 45 \mu \mathrm{m}$.

seen in large numbers only in the 2- and 3-week-old pups after SE. The distribution of these neurons was age-dependent, with the 2-week-olds demonstrating such injury predominantly in the CA1 region (Fig. 4A,C), the subiculum, and the thalamus, with lesser labeling of the inner dentate granule cells. In the 3 -week-old animals, only the inner layer of the dentate granule cells (Fig. $4 B, D)$ and a few thalamic neurons were TUNEL-positive. Fluorescence microscopy of EtBr-stained sections (Fig. 5A,B) revealed fragmented nuclei in the same areas that were TUNEL-stained. In the 3-week-old animals, the neuronal injury delineated by the
TUNEL and EtBr methods (Figs. $4 B, D, 5 B$ ) seen in the inner layer of the granule cells was different from that seen in the outer granular layer neurons visualized by their eosinophilic cytoplasm (Fig. 2B). Two types of damage also appear to coexist in the CA1 subfield of 2-week-old pups subjected to SE.

Electron micrographs of CA1 in 2-week-old pups (Fig. $6 A$ ) and of the inner granule cell region and hilus (Fig. $6 B$ ) of the 3-weekolds clearly demonstrated the presence of distinctive nuclear and cytoplasmic changes suggestive of necrosis in some neurons and of apoptosis in others. Twenty-four hours after SE, many CA1 

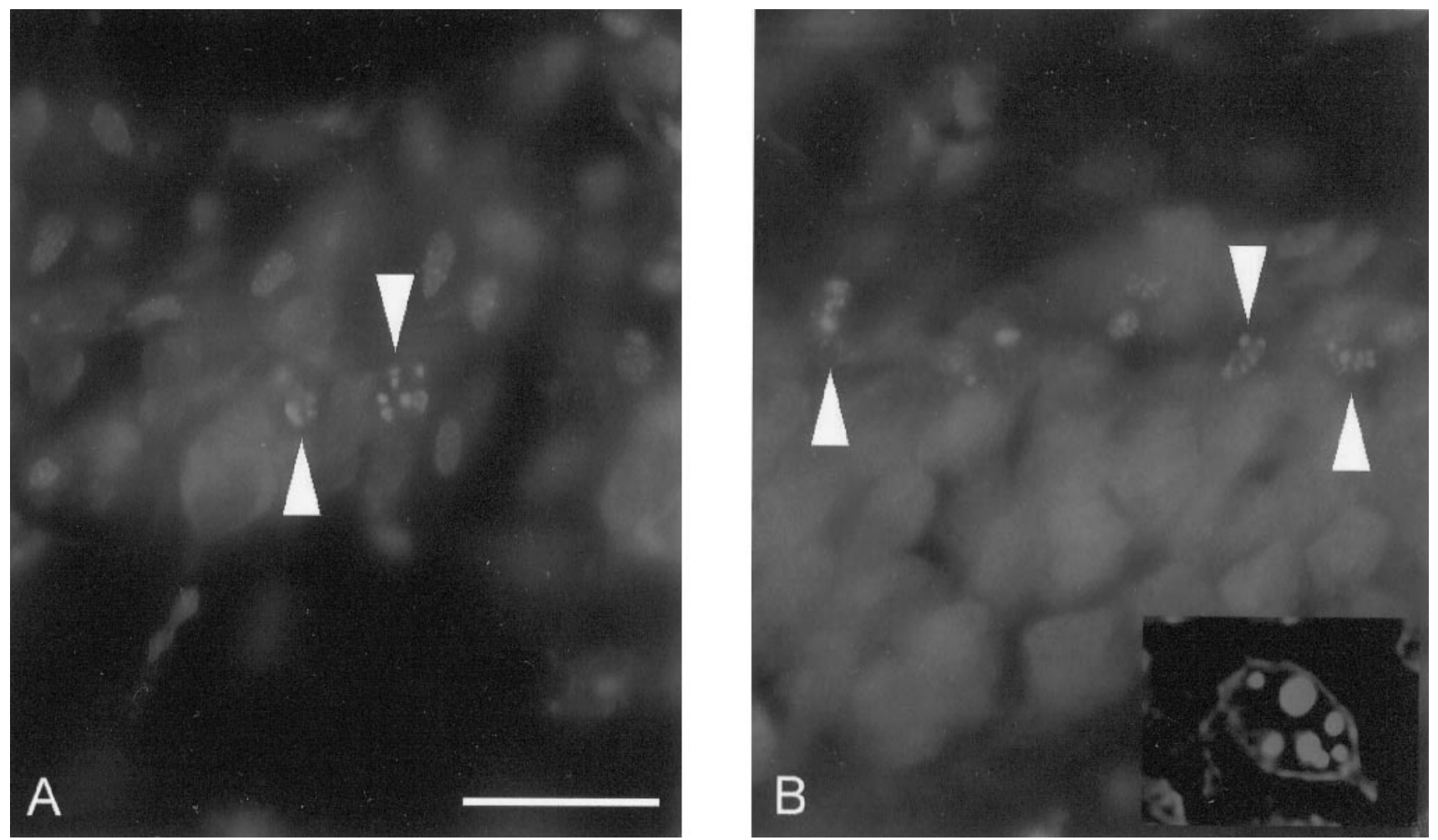

Figure 5. Ethidium bromide staining in the CA1 of a 2-week-old rat $(A)$ and the inner granule cell layer of a 3-week-old rat $(B)$. Arrowheads indicate fragmented nuclei. Scale bar, $18 \mu \mathrm{m}$. Inset in $B$ shows an exhaustive photon reassignment view of chromatin concretions in an apoptotic nucleus $(6 \mu \mathrm{m}$ diameter).

neurons displayed chromatin condensation coexisting with intact cytoplasmic and nuclear membranes and with relatively intact cytoplasmic organelles. In that same CA1 region, however, swollen neurons with ruptured membranes, extensive cytoplasmic damage, and all the hallmarks of necrosis were also seen. In the 3-week-old dentate gyrus, inner granule cells with chromatin margination and nearly intact cytoplasms were seen in close proximity to clearly necrotic hilar neurons.

The DNA extracted from the hippocampi of rats of various ages subjected to LiPC SE and of their age-matched controls was studied by agarose gel electrophoresis (Fig. 7). Laddering was not evident in the lanes in which DNA from control rats was placed. Discrete bands corresponding to fragments of DNA with a periodicity approximating 180 base pairs, suggesting oligonucleosomal breaks, were seen best in the hippocampal DNA from the 2and 3-week-old rats that underwent SE. A less prominent degree of laddering was also seen in the lanes containing DNA from the hippocampi and neocortices (the latter not shown) of 4-week-old and adult rats that underwent SE, although we did not see a significant number of TUNEL-positive neurons, or apoptotic bodies, at the two time points ( 24 and $72 \mathrm{hr}$ ) studied in those animals.

\section{Epileptogenesis}

Three of the 11 rats subjected to SE at 2 weeks of age that were observed for at least 4 months developed spontaneous seizures that resembled Racine's (1972) stages 3-5 in kindled animals and seizures triggered by handling. The latter were characterized by a few myoclonic jerks sometimes leading to a stage 3-5 seizure. Of the 11 rats subjected to SE at 3 weeks of age, eight (and six out of eight that experienced SE at 4 weeks) displayed spontaneous seizures after a latent period of $<3$ months, shorter than that seen in the animals subjected to SE at 2 weeks of age. Recordings of spontaneous seizures from a rat that underwent LiPC SE at 2 weeks is shown in Figure $8 A$, whereas Figure $8 B$ shows multiple spontaneous seizures recorded from a rat that experienced LiPC $\mathrm{SE}$ at 3 weeks of age.

\section{Mossy fiber synaptic reorganization}

The degree of staining seen in the rats that developed spontaneous seizures after undergoing SE at 2 weeks of age (Fig. $8 E$ ) was not distinguished from that of controls (Fig. $8 C$ ). The pattern of Timm staining of the inner molecular layer seen in a rat with spontaneous seizures that had undergone SE at 3 (Fig. $8 F$ ) and 4 weeks of age is similar to that seen in adults.

\section{DISCUSSION}

We have used different methods known to be sensitive to distinctive mechanisms that may lead to neuronal damage as a result of the recurrent excitation caused by SE during development. Previous studies by others (Albala et al., 1984; Sperber et al., 1991, 1992) have focused on specific aspects of hippocampal response to seizures such as hilar cell loss and mossy fiber sprouting and have remarked on the relative resiliency of the immature brain to seizures. Our results show enhanced vulnerability to CA1 neurons during early development at a stage when hilar injury and mossy fiber synaptic reorganization are not prominent. The damage seen at this age appears to involve both necrosis, as evidenced by the eosinophilic cells, and apoptosis as demonstrated by various techniques that included TUNEL staining, visualization of fragmented nuclei under fluorescence microscopy of EtBr-stained 

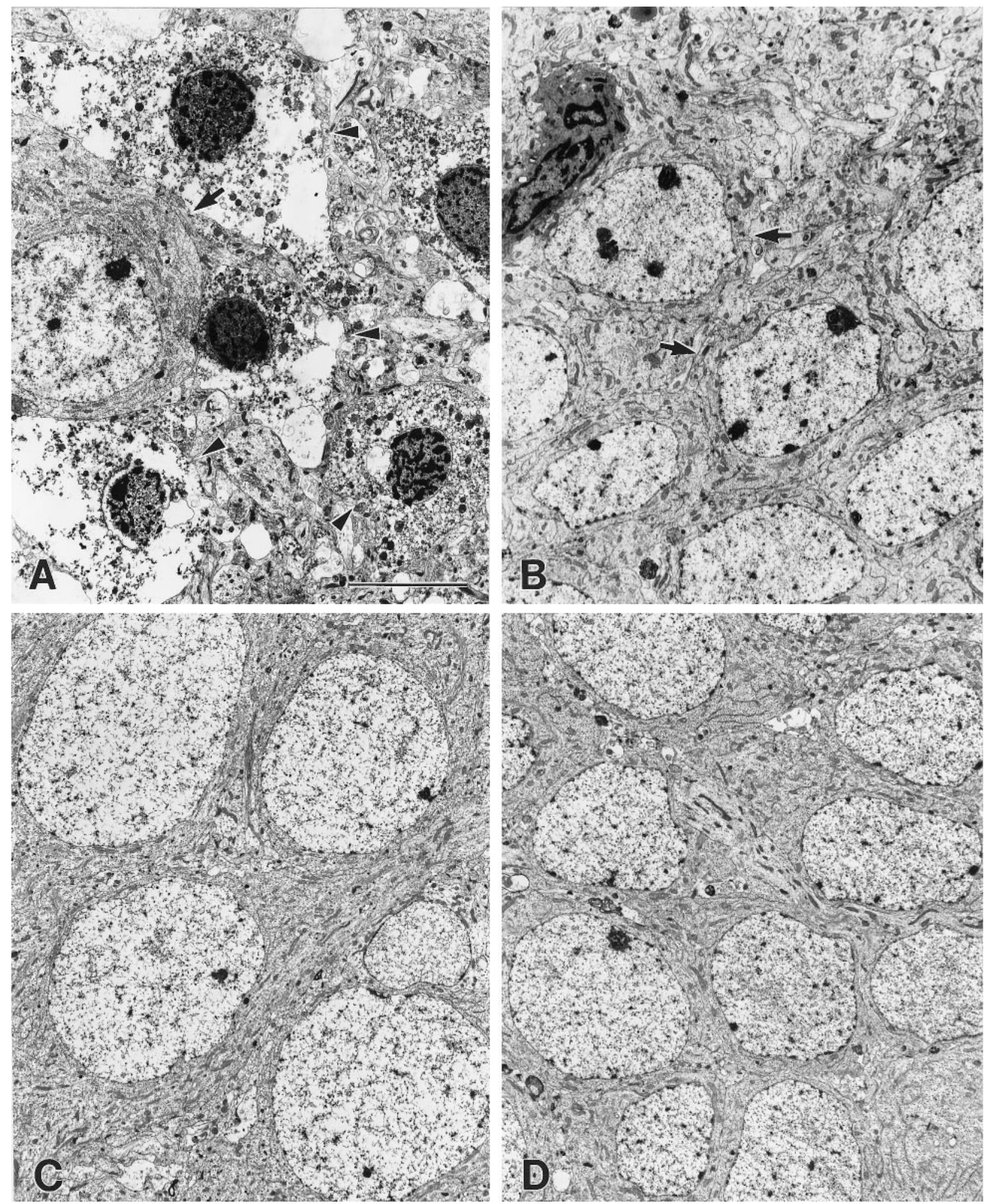

Figure 6. Electron micrographs in rat pups. The CA1 of a 2 week-old rat $(A)$ shows an apoptotic cell with condensed cytoplasm $($ arrow $)$ and several necrotic cells with shrunken nuclei and vacuolated cytoplasm (arrowheads). EM of the granule cells near the hilar border of a 3 week-old rat $(B)$ shows several apoptotic neurons. CA1 cells from a control 2-week-old pup and dentate granule cells from a control 3-week-old pup are shown in $C$ and $D$, respectively. Scale bar, $4 \mu \mathrm{m}$.

sections, and electron microscopy. We have also presented DNA electrophoresis data compatible with the process of apoptosis.

Franck and Schwartzkroin (1984) had found preferential loss of CA1 neurons in immature rabbits subjected to SE induced by systemic KA and had observed the similarity of this lesion to that induced by ischemia and/or hypoxia. It was subsequently shown in hippocampal slices obtained from immature rabbits that the rise in extracellular potassium after repetitive stimulation was 


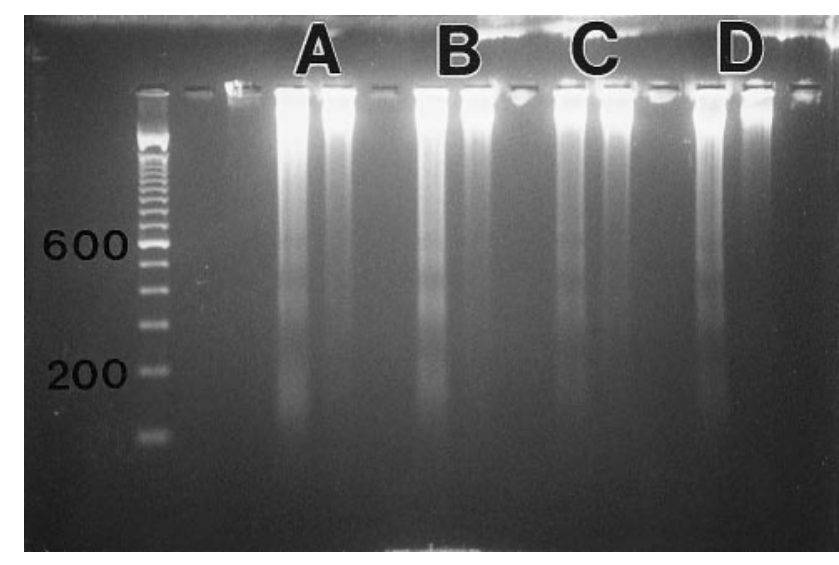

Figure 7. Paired agarose gel electrophoresis of hippocampal DNA from LiPC-treated (left lanes) and age-matched control rats (right lanes). Laddering pattern is visible in rats undergoing SE at all ages. Lanes in $A-D$ correspond to 2-, 3-, and 4-week-old and adult rats, respectively. Shown at left is 100 base pair standard.

regulated less effectively in CA1 compared with CA3 (Haglund and Schwartzkroin, 1990). More recently, such vulnerability of the CA1 neurons to LiPC SE has been demonstrated in immature rabbits in the absence of hypoxia (Thompson and Wasterlain, 1997). In the rat, Hamon and Heinemann (1988) had shown that during the second postnatal week, the apical dendrites of pyramidal neurons in area CA1 become more sensitive to NMDA, which is expressed by big influxes of calcium at this level. Harris and Teyler (1984) showed that long-term potentiation in area CA1 of the rat was maximal at $15 \mathrm{~d}$. Excitability comparable to that seen in fully mature animals could be demonstrated in the CA1 region after postnatal day 14 , whereas the inhibitory processes did not reach an adult stage of maturation until several weeks later (Michelson and Lothman, 1989). Our observation of preferential CA1 damage at 2 weeks of age is consistent with the observations of the development of synaptic inhibition lagging in CA1 compared with area CA3 (Swann et al., 1989) or the dentate gyrus (Bekenstein and Lothman, 1991). Target kainate receptor development at the mossy fiber terminals and amygdala reached maturation (Berger et al., 1984) only toward the end of the third week such that the hilus and CA3 are resistant to SE-induced damage in the 2-week-old rat.

In the CA1 region of the 2-week-old rat, both acidophilic neurons and TUNEL-positive neurons are seen in close proximity to each other. Our electron micrographs confirm the presence of nuclear profiles suggesting necrosis in the same region as those suggesting apoptosis. It has been shown that both apoptosis and necrosis can result from qualitatively similar types of excitotoxic stimulus, with the intensity of NMDA receptor activation deciding the process (Bonfoco et al., 1995). The neuronal damage seen maximally in the CA1 of our 2 week-old rats is attributable to the seizures, because hypoxia was not encountered in these animals. Furthermore, hypoxia at $\mathrm{Pa}_{\mathrm{O}_{2}}$ of $20 \mathrm{mmHg}$ for 20 min without ischemia did not result in cell loss or even morphological evidence of injury as evidenced by the lack of expression of heatshock protein in mature rats (Pearigen et al., 1996).

Damage to the hilus and CA3 in this model of SE appears to be at least as severe in the 3-week-old rat pups as in mature rats, but 2-week-old pups show little or no damage. The development of vulnerability to seizure-induced damage in the hilus and CA3 may be attributed to the maturation of the mossy fiber terminals.
This was suggested by Nitecka et al. (1984) in a detailed study of SE-induced damage in the KA model that documented progressive damage to limbic structures from postnatal day 18. Previous studies demonstrating resistance to SE-induced hilar and CA3 damage in the developing brain have compared mature rats only to 2-week-old pups (Albala et al., 1984; Sperber et al., 1991, 1992) in the kainic acid model or have used groupings such as 15- to 21-d-old rats in the PC model of SE (Cavalheiro et al., 1987).

Recent studies in immature animals have suggested that certain methods such as acid fuchsin staining (Chang and Baram, 1994) and silver degeneration methods (Toth et al., 1998) may delineate reversible neuronal injury rather than serve as markers of dying neurons. We have demonstrated that the pattern of neuronal damage discernible by eosin fluorescence at $24 \mathrm{hr}$ is reflected as permanent cell drop-out in cresyl violet-stained sections obtained from surviving rats several months after SE.

We saw evidence of damage to the granule cells of the dentate gyrus mainly in the 21 -d-old rat pups. It is striking that strongly eosinophilic neurons are seen mainly in the outermost layers of the granule cells, whereas scattered TUNEL-positive neurons are seen along the hilar border. The distribution of TUNEL-positive neurons in our experiments is reminiscent of the results reported by Goodman et al. (1993) in ischemic rat pups, and by Bengzon et al. (1997) after kindling or KA administration in adult rats. Apoptosis of granule cells has also been shown after repetitive perforant path stimulation (Sloviter et al., 1996) and after adrenalectomy (Sloviter et al., 1993; Hu et al., 1997), in mature rats. Under these circumstances, apoptosis does not appear to be restricted to the granule cells along the hilar border. In hypoxicischemic rat pups, the distribution of apoptosis was limited to the inner granule cells that did not express the calcium-binding protein calbindin D28k, suggesting a mechanism for this agedependent vulnerability, which might also apply to our pups.

Weiss et al. (1996) reported a significantly different pattern of DNA fragmentation in the hippocampus of rats subjected to KA-induced SE. It is likely that the pattern of DNA fragmentation detected by a particular technique is influenced by the timing after the excitotoxic insult as well as the variations in the technique. Didier et al. (1996) have suggested that the in situ nick translation method using DNA polymerase 1 is very sensitive and labels single-strand breaks and that such damage may be reversible, whereas the nick end labeling with terminal deoxynucleotidyl transferase identifies double-strand breaks.

Charriaut-Marlangue and Ben-Ari (1995) cautioned on the use of the TUNEL stain as the sole criterion for the demonstration of apoptosis and suggested that methods such as Hoechst 33258 staining be used to supplement the data. We have used EtBr staining in such a manner. It is of interest that significant TUNEL labeling was not seen in our experiments in regions where extensive eosinophilic neurons are encountered in animals older than the 3 week-old pups. This is consistent with the results of Fujikawa et al. (1997) who did not see significant evidence for apoptosis in mature rats subjected to LiPC SE. On the other hand, "DNA laddering" on agarose gel is widely presented as evidence of apoptosis based on the suggestion that necrosis would lead to a "smear" DNA pattern (Walker et al., 1994). Our results show that laddering may be seen when there is extensive necrosis, although cells matching the morphological criteria for apoptosis may be extremely rare. Similar observations have been made by Fujikawa et al. (1997). These results are consistent with recent reports that examined the consequences of excitotoxic exposure of cultured murine cortical neurons (Gwag et al., 1997; Sohn et 
A
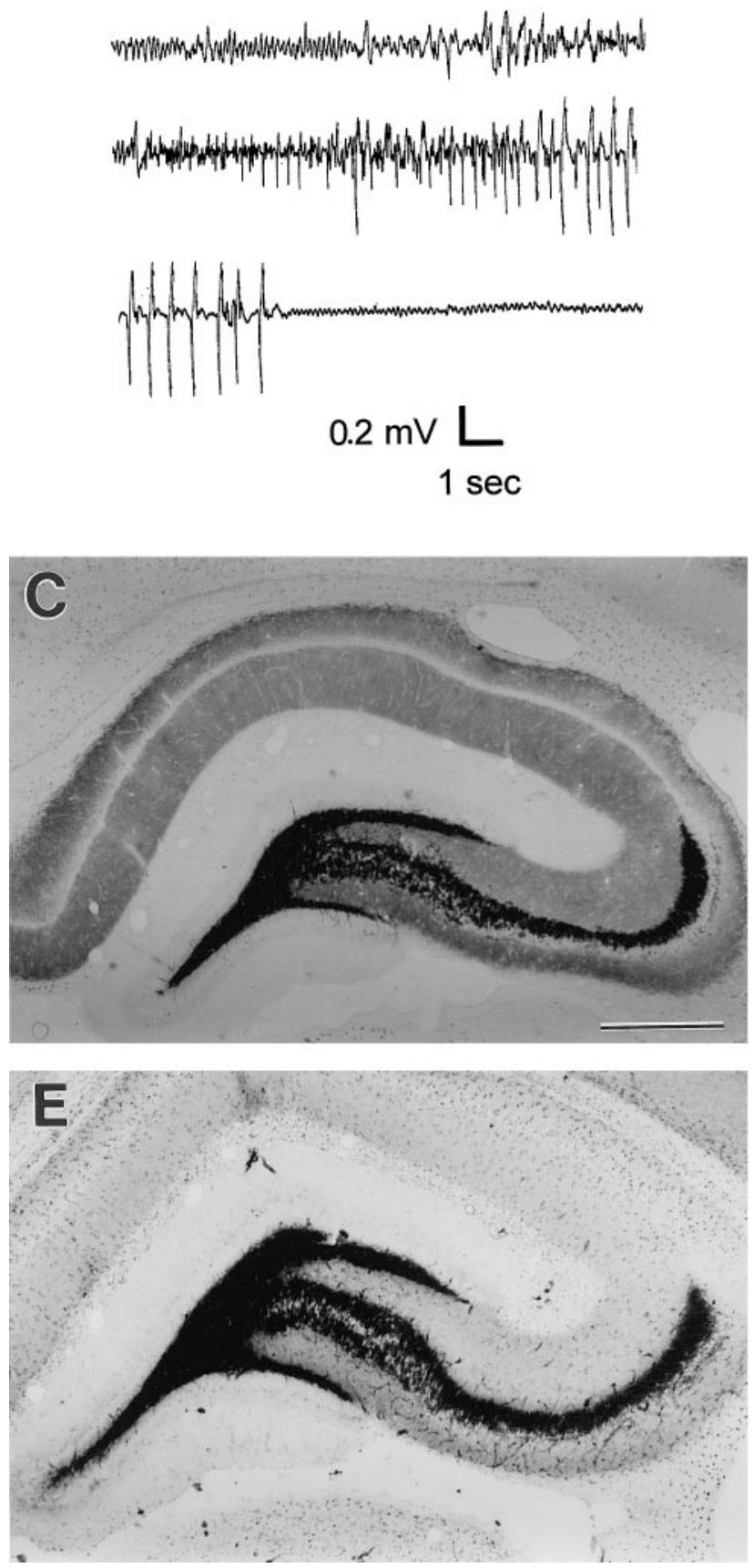

B
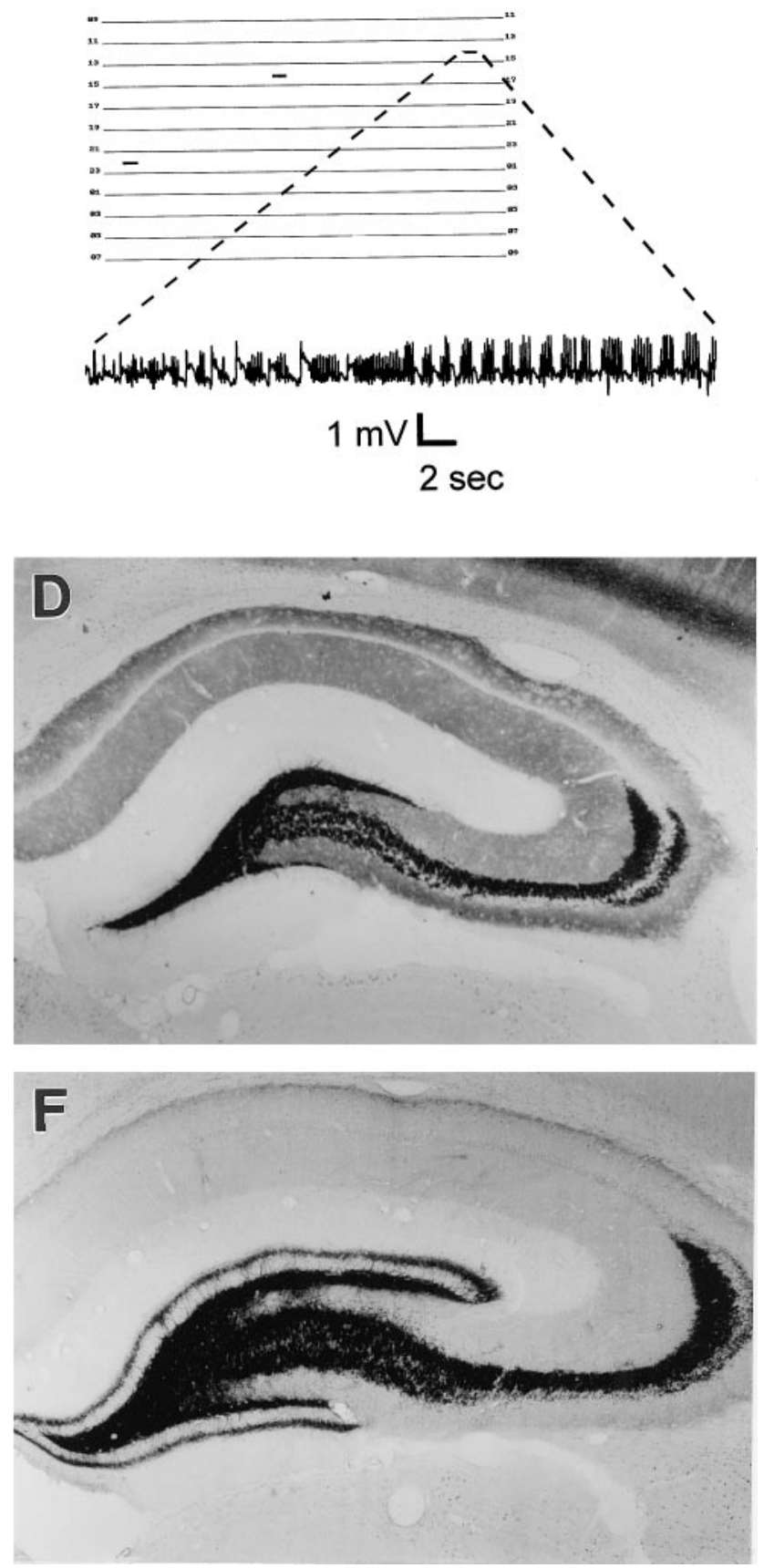

Figure 8. Spontaneous seizures and sprouting in adult rats after treatment with LiPC as pups. $A$, A hippocampal EEG recording accompanied by a stage 5 behavioral convulsion 6 months after SE at 2 weeks of age. $B$, Continuous monitoring of a rat 3 months after LiPC treatment at 3 weeks of age shows several spontaneous seizures during a $24 \mathrm{hr}$ period. Each line represents $2 \mathrm{hr}$. Black bar shows an electrographic seizure captured by the software, accompanied by stage 4 behavioral convulsions. Electrographic seizure is outlined by the dashed line. Mossy fiber sprouting is not seen in control rats treated at 2 weeks $(C)$ and 3 weeks of age $(D)$. E. Timm staining of the mature rat in $A$ that was given LiPC at 2 weeks of age is not discernible from an age-matched control $(C)$, whereas dense Timm staining of the inner molecular layer is seen in a pup given LiPC at 3 weeks of age $(F)$. Scale bar, $500 \mu \mathrm{m}$.

al., 1998). In these studies, early cell swelling and early damage to the plasma membrane were observed when the integrity of the nuclear membrane was preserved along with DNA ladders. Hence, we would like to sound a cautionary note on the use of agarose gel electrophoresis of extracted DNA as a sole or major criterion for apoptosis.
Rat pups that were subjected to SE at 2 weeks of age developed spontaneous seizures after a longer latency than those that underwent SE at P21, and in much smaller (3/11 vs 8/11, respectively) numbers. Even the rats that developed spontaneous seizures after SE at 2 weeks of age did not show evidence of sprouting as seen by Timm stain. A recent report had suggested 
(Longo and Mello, 1997) that spontaneous seizures could develop after $\mathrm{SE}$ in the absence of mossy fiber sprouting. This conclusion was based on experiments in which sprouting had been blocked by the administration of cycloheximide, a protein synthesis inhibitor, without abolishing the development of spontaneous seizures. Our results do not distinguish whether sprouting and synaptic reorganization of the mossy fiber pathway is a cause or result of repeated seizures.

In conclusion, we have shown that the pattern of seizureinduced cell death is related to development. Apoptosis and necrosis can result from seizures in an age-dependent distribution, and even young animals can develop spontaneous seizures as a consequence of early seizures. The demonstration of seizurerelated apoptosis in the immature brain may have implications for the development of neuroprotective agents tailored for use in the young.

\section{REFERENCES}

Albala BJ, Moshé SL, Okada R (1984) Kainic-acid-induced seizures: a developmental study. Brain Res 315:139-148.

Bekenstein JW, Lothman EW (1991) A comparison of the ontogeny of excitatory and inhibitory neurotransmission in the CA1 region and dentate gyrus of the rat hippocampal formation. Dev Brain Res 63:237-243.

Bengzon J, Kokaia Z, Elmer E, Nanobashvili A, Kokaia M, Lindvall O (1997) Apoptosis and proliferation of dentate gyrus neurons after single and intermittent limbic seizures. Proc Natl Acad Sci USA 94:10432-10437.

Berger ML, Tremblay E, Nitecka L, Ben-Ari Y (1984) Maturation of kainic acid seizure-brain damage syndrome in the rat. III. Postnatal development of kainic acid binding sites in the limbic system. Neuroscience 13:1095-1104.

Bonfoco E, Krainc D, Ankarcrona M, Nicotera P, Lipton SA (1995) Apoptosis and necrosis: two distinct events induced, respectively, by mild and intense insults with $N$-methyl-D-aspartate or nitric oxide/ superoxide in cortical cell cultures. Proc Natl Acad Sci USA 92:7162-7166.

Brown AW, Brierley JB (1968) The nature, distribution and earliest changes of anoxic-ischemic nerve cell damage in the rat brain as defined by the optical microscope. Br J Exp Pathol 49:87-106.

Camfield PR (1997) Recurrent seizures in the developing brain are not harmful. Epilepsia 38:735-737.

Cavalheiro EA (1995) The pilocarpine model of epilepsy. Ital J Neurol Sci 16:33-37.

Cavalheiro EA, Silva DF, Turski WA, Calderazzo FL, Bortolotto ZA, Turski L (1987) The susceptibility of rats to pilocarpine-induced seizures is age-dependent. Brain Res 465:43-58.

Cavalheiro EA, Santos NF, Priel MR (1996) The pilocarpine model of epilepsy in mice. Epilepsia 37:1015-1019.

Chang D, Baram TZ (1994) Status epilepticus results in reversible neuronal injury in infant rat hippocampus: novel use of a marker. Dev Brain Res 77:133-136.

Charriaut-Marlangue C, Ben-Ari Y (1995) A cautionary note on the use of the TUNEL stain to determine apoptosis. NeuroReport 7:61-64.

Clifford DB, Olney JW, Maniotis A, Collins RC, Zorumski CF (1987) The functional anatomy and pathology of lithium-pilocarpine and highdose pilocarpine seizures. Neuroscience 23:953-968.

Danscher G (1981) Histochemical demonstration of heavy metals. A revised version of the sulphide silver method suitable for both light and electronmicroscopy. Histochemistry 71:1-16.

Didier M, Bursztajn S, Adamec E, Passani L, Nixon RA, Coyle JT, Wei JY, Berman SA (1996) DNA strand breaks induced by sustained glutamate excitotoxicity in primary neuronal cultures. J Neurosci 16:2238-2250.

Filipkowski RK, Hetman M, Kaminska B, Kaczmarek L (1994) DNA fragmentation in rat brain after intraperitoneal administration of kainate. NeuroReport 5:1538-1540.

Franck JE, Schwartzkroin PA (1984) Immature rabbit hippocampus is damaged by systemic but not intraventricular kainic acid. Brain Res 315:219-227.

Fujikawa DG (1995) Neuroprotective effect of ketamine administered after status epilepticus onset. Epilepsia 36:186-195.
Fujikawa DG, Daniels AH, Kim JS (1994) The competitive NMDA receptor antagonist CGP 40116 protects against status epilepticusinduced neuronal damage. Epilepsy Res 17:207-219.

Fujikawa DG, Cai BB, Shinmei SS, Allen SG (1997) Neuronal death induced by lithium-pilocarpine-induced seizures is necrotic, not apoptotic. Soc Neurosci Abstr 23:1112.

Goodman JH, Wasterlain CG, Massarweh WF, Dean E, Sollas AL, Sloviter RS (1993) Calbindin-D28k immunoreactivity and selective vulnerability to ischemia in the dentate gyrus of the developing rat. Brain Res 606:309-314.

Gwag BJ, Koh JY, DeMaro JA, Ying HS, Jacquin M, Choi DW (1997) Slowly triggered excitotoxicity occurs by necrosis in cortical cultures. Neuroscience 77:393-401.

Haglund MM, Schwartzkroin PA (1990) Role of Na-K pump potassium regulation and IPSPs in seizures and spreading depression in immature rabbit hippocampal slices. J Neurophysiol 63:225-239.

Hamon B, Heinemann U (1988) Developmental changes in neuronal sensitivity to excitatory amino acids in area CA1 of the rat hippocampus. Brain Res 466:286-290.

Harris KM, Teyler TJ (1984) Developmental onset of long-term potentiation in area CA1 of the rat hippocampus. J Physiol (Lond) 346:27-48.

Hirsch E, Baram TZ, Snead III OC (1992) Ontogenic study of lithiumpilocarpine-induced status epilepticus in rats. Brain Res 583:120-126.

Honchar MP, Olney JW, Sherman WR (1983) Systemic cholinergic agents induce seizures and brain damage in lithium-treated rats. Science 220:323-325.

Hu Z, Yuri K, Ozawa H, Lu H, Kawata M (1997) The in vivo time course for elimination of adrenalectomy-induced apoptotic profiles from the granule cell layer of the rat hippocampus. J Neurosci 17:3981-3989.

Iwasa M, Maeno Y, Inoue H, Koyama H, Matoba R (1996) Induction of apoptotic cell death in rat thymus and spleen after a bolus injection of methamphetamine. Int J Legal Med 109:23-28.

Jope RS, Morrisett RA, Snead OC (1986) Characterization of lithium potentiation of pilocarpine-induced status epilepticus in rats. Exp Neurol 91:471-480.

Kornblum HI, Sankar R, Shin DH, Wasterlain CG, Gall CM (1997) Induction of brain derived neurotrophic factor mRNA by seizures in neonatal and juvenile rat brain. Mol Brain Res 44:219-228.

Liu Z, Gatt A, Werner SJ, Mikati MA, Holmes GL (1994) Long-term behavioral deficits following pilocarpine seizures in immature rats. Epilepsy Res 19:191-204.

Longo BM, Mello LE (1997) Blockade of pilocarpine- or kainateinduced mossy fiber sprouting by cycloheximide does not prevent subsequent epileptogenesis in rats. Neurosci Lett 226:163-166.

Meldrum BS, Vigouroux RA, Brierley JB (1973) Systemic factors and epileptic brain damage. Prolonged seizures in paralyzed, artificially ventilated baboons. Arch Neurol 29:82-87.

Michelson HB, Lothman EW (1989) An in vivo electrophysiological study of the ontogeny of excitatory and inhibitory processes in the rat hippocampus. Dev Brain Res 47:113-122.

Morrison RS, Wenzel HJ, Kinoshita Y, Robbins CA, Donehower LA, Schwartzkroin PA (1996) Loss of the p53 tumor suppressor gene protects neurons from kainate-induced cell death. J Neurosci 16:1337-1345.

Nevander G, Ingvar M, Auer R, Siesjo BK (1985) Status epilepticus in well-oxygenated rats causes neuronal necrosis. Ann Neurol 18:281-290.

Nitecka L, Tremblay E, Charton G, Bouillot JP, Berger ML, Ben-Ari Y (1984) Maturation of kainic acid seizure-brain damage syndrome in the rat. II. Histopathological sequelae. Neuroscience 13:1073-1094.

Okada R, Moshé SL, Albala BJ (1984) Infantile status epilepticus and future seizure susceptibility in the rat. Brain Res 317:177-183.

Paxinos G, Watson C (1982) The rat brain in stereotaxic coordinates. Sydney: Academic.

Pearigen P, Gwinn R, Simon RP (1996) The effects in vivo of hypoxia on brain injury. Brain Res 725:184-191.

Penix LP, Wasterlain CG (1994) Selective protection of neuropeptide containing dentate hilar interneurons by non-NMDA receptor blockade in an animal model of status epilepticus. Brain Res 644:19-24.

Penix LP, Thompson KW, Wasterlain CG (1996) Selective vulnerability to perforant path stimulation: role of NMDA and non-NMDA receptors. Epilepsy Res [Suppl] 12:63-73.

Pollard H, Charriaut-Marlangue C, Cantagrel S, Represa A, Robain O, 
Moreau J, Ben-Ari Y (1994) Kainate-induced apoptotic cell death in hippocampal neurons. Neuroscience 63:7-18.

Portera-Cailliau C, Price DL, Martin LJ (1997a) Excitotoxic neuronal death in the immature brain is an apoptosis-necrosis morphological continuum. J Comp Neurol 378:70-87.

Portera-Cailliau C, Price DL, Martin LJ (1997b) Non-NMDA and NMDA receptor-mediated excitotoxic neuronal deaths in adult brain are morphologically distinct: further evidence for an apoptosis-necrosis continuum. J Comp Neurol 378:88-104.

Racine RJ (1972) Modification of seizure activity by electrical stimulation. II. Motor seizure. Electroencephalogr Clin Neurophysiol 32:281-294.

Sankar R, Wasterlain CG, Sperber EF (1995) Seizure-induced changes in the immature brain. In: Brain development and epilepsy (Schwartzkroin PA, Moshé SL, Swann JW, Noebels JL, eds), pp 268-288. New York: Oxford UP.

Sankar R, Shin DH, Lezama R, Liu H, Santos D, Pulera M, Allen S, Wasterlain CG (1997a) Seizure-induced apoptosis and necrosis in the developing brain is age-dependent. Soc Neurosci Abstr 23:807.

Sankar R, Shin DH, Wasterlain CG (1997b) Serum neuron-specific enolase is a marker for neuronal damage following status epilepticus in the rat. Epilepsy Res 28:129-136.

Sloviter RS, Dean E, Neubort S (1993) Electron microscopic analysis of adrenalectomy-induced hippocampal granule cell degeneration in the rat: apoptosis in the adult central nervous system. J Comp Neurol 330:337-351.

Sloviter RS, Dean E, Sollas AL, Goodman JH (1996) Apoptosis and necrosis induced in different hippocampal neuron populations by repetitive perforant path stimulation in the rat. J Comp Neurol 366:516-533.

Sohn S, Kim EY, Gwag BJ (1998) Glutamate neurotoxicity in mouse cortical neurons: atypical necrosis with DNA ladders and chromatin condensation. Neurosci Lett 240:147-150.

Sperber EF, Haas KZ, Stanton PK, Moshé SL (1991) Resistance of the immature hippocampus to seizure-induced synaptic reorganization. Dev Brain Res 60:88-93.

Sperber EF, Haas KZ, Moshé SL (1992) Developmental aspects of status epilepticus. Int Pediatr 7:213-222.

Swann JW, Brady RJ, Martin DL (1989) Postnatal development of GABA-mediated synaptic inhibition in rat hippocampus. Neuroscience 28:551-561.

Thompson K, Wasterlain C (1997) Lithium-pilocarpine status epilepticus in the immature rabbit. Dev Brain Res 100:1-4.

Thompson K, Holm AM, Schousboe A, Popper P, Micevych P, Wasterlain C (1998) Hippocampal stimulation produces neuronal death in the immature brain. Neuroscience 82:337-348.

Toth Z, Yan XX, Haftoglou S, Ribak CE, Baram TZ (1998) Seizureinduced neuronal injury: vulnerability to febrile seizures in an immature rat model. J Neurosci 18:4285-4294.

Turski WA, Cavalheiro EA, Schwarz M, Czuczwar S-LJ, Kleinrok Z, Turski L (1983) Limbic seizures produced by pilocarpine in rats: behavioural, electroencephalographic and neuropathological study. Behav Brain Res 9:315-335.

Walker PR, Weaver VM, Lach B, LeBlanc J, Sikorska M (1994) Endonuclease activities associated with high molecular weight and internucleosomal DNA fragmentation in apoptosis. Exp Cell Res 213:100-106.

Wasterlain CG (1997) Recurrent seizures in the developing brain are harmful. Epilepsia 38:728-734.

Weiss S, Cataltepe O, Cole AJ (1996) Anatomical studies of DNA fragmentation in rat brain after systemic kainate administration. Neuroscience 74:541-551. 